\title{
Adverse Event Start Date
}

National Cancer Institute

\section{Source}

National Cancer Institute. Adverse Event Start Date. NCI Thesaurus. Code C78536.

The calendar date on which an adverse event starts. 